\title{
The Development of Researchers' Ethics Using Practical Classroom Training for Marketing Students, Faculty of Management Science, Thepsatri Rajabhat University, Thailand
}

\author{
Panitsupa Thampramuan \\ Faculty of Management Science, \\ Thepsatri Rajabhat University, \\ Lop Buri,Thailand. \\ thampanit@hotmail.com
}

\begin{abstract}
Every students studying marketing research for marketing decision should develop a research ethics by practicing to achieve the goal. The student will be a good market researcher with ethics and morals suitable for being a qualified researcher in the future.This research was aimed to develop researchers' ethics using practical classroom training for 30 marketing students of the Faculty of Management Science at Thepsatri Rajabhat University in Thailand during the academic year 2017. This research employed interactive learning through actions (ILTA) approach incorporating the cycle of Plan $(P)$, Act (A), Observe (O), and Reflect (R). Data were collected from a questionnaire on researchers' ethics administered to the students before and after the training. The questionnaire included a five-point rating scale in 8 aspects namely: 1) honesty and morals in academic endeavor and research procedures, 2) worthiness of research, 3) responsibility for both animated and unanimated research samples, 4) respect for participants' integrity and rights, 5) freedom in expressing thoughts without prejudice in every research procedure, 6) application of research outcomes in a righteous manner, 7) respect for others' academic viewpoints, and 8) responsibility for every social stratum. Data were analyzed in terms of mean, standard deviation, and paired sample t-test. Findings were as follows: 1) Overall the aspects of the students' research ethics after the training were at a good level. 2) After the training, all the aspects of the students' research ethics were found to be significantly higher than those before the training significantly at $\mathbf{. 0 0 1}$. However, the scores on the aspects of "Respect for participants' integrity and rights," and "Respect for others' academic viewpoints" were not significantly higher after the training.
\end{abstract}

Keywords: development of researchers' ethics, practical classroom training

\section{INTRODUCTION}

Ethics in Research is an important element of research methodology. In the research process researchers must be closely related to what is being studied, whether living or non-living. Research may have a negative impact on the study if the researcher is cautious. The quality of the research depends on the researcher's ability to study and on the morality of the researcher in the research. If the research's results are bad and/or if it is released, may be harmful to the academic and the nation [1].

Moral and ethical skills are the first skills listed in TQF ( Thailand Qualification Framework) . It is focused on developing learning outcomes of students in all courses. This is a valuable skill that has to be developed through the process of learning in higher education.

The teaching and learning practice is the introduction of knowledge from the subject matter of research to the marketing decision making to achieve holistic learning. It is the combination of learning power that makes the students inclusive morally, ethically and personally, within the community and the society. At the same time, it creates a learningcentered community. The learner selects the issues that interest the student, engages in planning and provides learning activities that match the interests of the learners and the problems and/or needs of the community. One way to solve ethical problems of students is to seriously promote ethical morals, like Prasong Thongpra, Taweesak Thongtip, Banjong, Sodadee, and Thanu Thongsri [2]. Promoting the solution to the problem of moral inadequacy of a 
student is serious in order to enhance morality. The researcher must integrate moral and ethics into the core subjects and ethical behavior must be taken as part of the evaluation of the course in all marketing research disciplines. Morality, ethics, and good research should be developed in details of the role and importance of marketing research to the business. The Marketing Research Process Determining used to identify the problems in market research and research proposal is as follows: (1) Research Design, Population Design and sampling data collection, (2) Data processing Analysis and interpretation of data, (3) Marketing Research Application, (4) Practice computer skills in data processing, (5) Analyze quantitative data, and (6) Market research report to be used as a guide to business decision. The students must have high responsibility. Attempts to learn both theory and practice are high. Assist each other in the group and meet the instructors regularly. Track assigned tasks and deliver in a timely manner. In the past, most of the students did not work in each step. Delay the next step and it cannot work as scheduled. Teachers provide time off work for some groups and extend the delivery time. Some groups do not follow the research process. It has a positive effect on learning achievement. Record the summary of the findings in the study regarding the method of teaching development.

Therefore, every student studying marketing research for marketing decision should develop a research ethics by practicing to achieve the goal. The student will be a good market researcher with ethics and morals suitable for being a qualified researcher in the future.

\section{OBJECTIVES}

To develop researchers' ethics using practical classroom training for marketing students in the Faculty of Management Science at Thepsatri Rajabhat University in Thailand.

\section{RESEARCH METHOD}

\section{A. Subject}

The sample consisted of 30 marketing students who enrolled in marketing research and decision making course, during the 2017 academic year, the Faculty of Management Science at Thepsatri Rajabhat University during the academic year 2017.

\section{B. Research Instruments}

Research instruments consisted of final test and researchers' ethics rating scale, before and after the training, included a five-point rating scale, $(5=$ very good, 4 = good, $3=$ average, $2=$ poor, $1=$ very poor $)$, in 8 aspects namely:

1) Honesty and morals in academic endeavor and research procedures

2) Worthiness of research
3) Responsibility for both animated and unanimated research samples

4) Respect for participants' integrity and rights

5) Freedom in expressing thoughts without prejudice in every research procedure

6) Application of research outcomes in a righteous manner

7) Respect for others' academic viewpoints

8) Responsibility for every social stratum

\section{Research Method and Process}

This research employed interactive learning through actions (ILTA) approach incorporating the cycle of

P-A-O-R:

1) P-plan included
a) Selection of topics /research problems
b) Studying theory
c) Research objectives
d) Variables / research framework
e) Research methodological design
f) Measurement design
g) Population and sampling design
h) Data collecting
i) Data analyzing and conclusion
j) Research report writing

2) A-act: practical classroom training by interactive learning through actions (ILTA). Each group, including five marketing students, was assigned to choose a topic of the interested of marketing research.

3) O-observe: by using research instruments

a) Final test

b) Researchers' ethics rating scale, before and after the training, included a five-point rating scale, $(5=$ very good, $4=$ good, $3=$ average, $2=$ poor, $1=$ very poor), in 8 aspects.

4) R-Reflect: analyzing and conclusion

a) Evaluation of a researchers' ethics

b) Evaluation of achievement

c) Conclusion and research report writing

\section{Data Analysis}

1) Evaluation of a researchers' ethics by using descriptive statistics; frequency, percentage, means, and standard deviation. The scale of the means used was; 4.50-5.00 = very good, 3.50-4.49= good, 2.50$3.49=$ fair, $1.50-2.49=$ poor , and $1.00-1.49=$ very poor)

2) Compared researchers' ethics before and after the training, by using inference statistics, paired sample t-test at .05 level of significance. 


\section{RESEARCH RESULTS}

Overall and all aspects of the students' research ethics after the training were at a good level as follows:

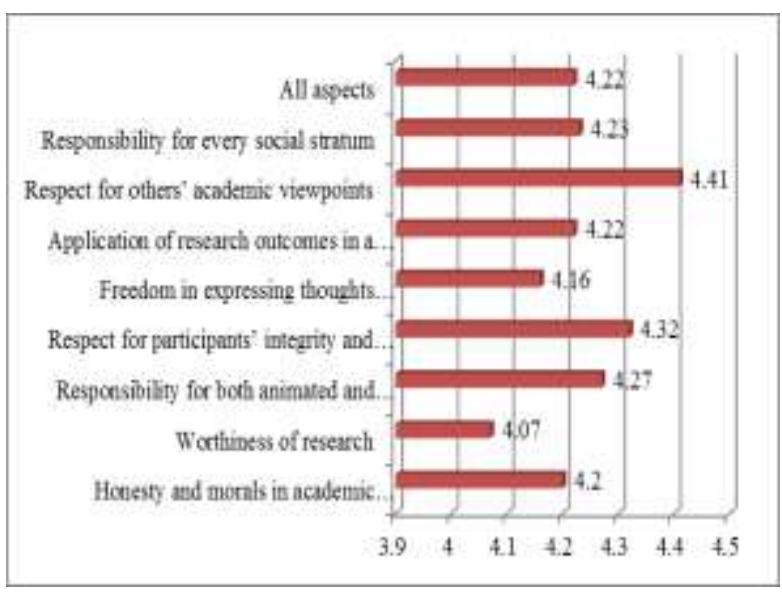

Fig. 1. Overall and all aspects, the students' research ethics after the training were at a good level

After the training, all the aspects of the students' research ethics were found to be significantly higher than those before the training $(\mathrm{p}<.001)$. However, the scores on the aspects of "Respect for participants' integrity and rights," and "Respect for others' academic viewpoints" were not significantly higher after the training.

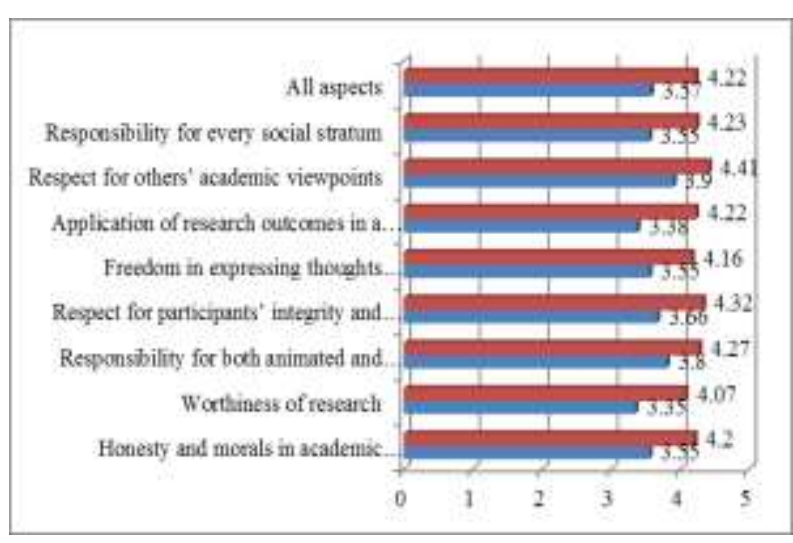

Fig. 2. Results of all aspects of the students' research ethics after the training

TABLE I. COMPARED RESEARCHERS' ETHNICS RESULTS, BEFORE AND AFTER TRAINING

\begin{tabular}{|c|c|c|c|}
\hline Researchers' ethics & t-test & Sig. & Results \\
\hline $\begin{array}{l}\text { 1. Honesty and morals in } \\
\text { academic endeavor and Research } \\
\text { procedures }\end{array}$ & $\begin{array}{c}- \\
4.887\end{array}$ & .000 & developed \\
\hline 2. Worthiness of research & $\begin{array}{c}- \\
4.568\end{array}$ & .000 & developed \\
\hline $\begin{array}{ll}\text { 3. Responsibility } & \text { for both } \\
\text { animated and } & \text { unanimated } \\
\text { research samples } & \end{array}$ & $\begin{array}{c}- \\
3.627\end{array}$ & .001 & developed \\
\hline
\end{tabular}

\begin{tabular}{|c|c|c|c|}
\hline $\begin{array}{l}\text { 4. Respect for participants' } \\
\text { integrity and rights }\end{array}$ & $\begin{array}{c}- \\
5.353 \\
\end{array}$ & .000 & developed \\
\hline $\begin{array}{l}5 . \quad \text { Freedom in expressing } \\
\text { thoughts without prejudice in } \\
\text { every research procedure }\end{array}$ & $\begin{array}{c}- \\
4.265\end{array}$ & .000 & developed \\
\hline $\begin{array}{l}\text { 6. Application of research } \\
\text { outcomes in a righteous manner }\end{array}$ & $5 . \overline{349}$ & .000 & developed \\
\hline $\begin{array}{l}\text { 7. Respect for others' academic } \\
\text { viewpoints }\end{array}$ & $\overline{-}$ & .000 & developed \\
\hline $\begin{array}{l}\text { 8. Responsibility for every social } \\
\text { stratum }\end{array}$ & $\begin{array}{c}- \\
4.971 \\
\end{array}$ & .000 & developed \\
\hline All aspects & $5 .-$ & .000 & developed \\
\hline
\end{tabular}

\section{DISCUSSION AND SUGGESTIONS}

\section{A. Discussion}

Code of Ethics for Researchers overall level is good. When considering each aspect, it was found that the level was high in all aspects, and higher than before learning by practicing as a whole in every aspect. This is consistent with Chitrapha Kunthonbutr which states the ethics for researchers [3]. This should be used as a guideline on conduct of the researcher. This guideline helps to conduct research, based on ethics and the appropriate academic principles. The standard of research is to honor the dignity and prestige of researchers and not conclude that the researcher's behavior was unethical. The most common unethical problems are the following: 1) to change the storage location or change the sample storage location, 2) information in the research report was not cited, 3) researcher does not devote knowledge, ability and time fully to the research, 4) deviation of research results to provide the findings of the research, and 5) accept the hypothesis or hope for personal benefit. It should be consistent with the criticism of Panich who found that those whom conducted systematic research answer the question [4]. The methodology accepted in each of the relevant sciences. In addition, the researcher must show proper conduct both moral and ethical. This is vital in professional practice to maintain reputation ones and promote the honor of their profession.

\section{B. Suggestions}

Students have to choose the subject they are interested in and have access to the resources they need. This will be an advantage in the work, follow the research process, achieve the objectives and achieve academic achievement.

Moreover, Code of Ethics for Researchers: The overall level is very high. When considering each aspect, it was found that the level was high in all aspects and higher than before learning by practice. Therefore, students should follow the learning process by practicing to raise awareness and appreciation of research as well as the ethics and ethics of the researcher to make the research valuable to the academic community and the nation. 


\section{ACKNOWLEDGMENT}

I would like to express my very great appreciation to Thepsatri Rajaphat University, and Faculty of Management Science who financially support this research project.

\section{REFERENCES}

[1] National Research Council Executive Board.. Researchers' Ethics. Printing Chulalongkorn University pp. 22 (1998).

[2] Prasong Thongprad, Thaveesak Thongtip,

Banjong Tanaddee, and Thanu Srichong . A study of the solution to the problem of moral inadequacy of higher education students in Surin province. Mahachulalongkorn

Rajavidyalaya University Surin Campus

Mahachulalongkornrajavidyalaya University. 2004.

[3] Chitrapha Kunthonbutr, Research for new generation researchers. Bangkok: Sahadhammic, 2007.

[4] Panich Wijaan, Research Management Experience concept 4th edition Research Fund. 2010. 